\title{
Ethics And Banking: Beyond Compliance
}

\author{
James A. Nelson, Ph.D., New Mexico State University, USA
}

\begin{abstract}
This case explores ethics beyond regulatory compliance in the banking industry. The reader discovers how bankers are exposed to ethical situations that are not subject to legal or regulatory controls. The personal ethical standards of a bank president are intended to prevent any perception of pay-to-play or conflict of interest. The reader is asked to respond to the case in three parts and to consider the unintended consequence of ethical standards on the bank's employees. This case is appropriate for courses in Ethics, Banking, and Government.
\end{abstract}

Keywords: Ethics and Banking; Regulatory Compliance; Business Case Study

\section{INTRODUCTION}

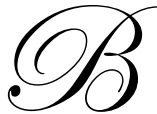

anks are regulated in the United States by several agencies, depending on their charter. All banks in the United States, regardless of their charter, are required to comply with regulations that have ethical implications. Banks designated as National Banks are regulated by the Office of the Comptroller of Currency (OCC), even though they may not operate nationally. State banks are charted by the state in which they are headquarters are located, but are almost always also regulated by the federal government as members of the Federal Deposit Insurance Corporation (FDIC). Savings and Loan banks and Credit Unions are regulated by the Office of Thrift Supervision (OTS) and the National Credit Union Administration (NCUA), respectively.

Each of these regulatory agencies not only ensures the "safety and soundness" of the bank's operations and services but also focuses on preventing fraud, ensuring privacy, providing equal access to loans to low-income populations, detecting terrorism and money laundering, and anti-usury protections. Compliance is the term used when a bank meets the legal requirements of the regulations. If a bank is not in compliance, it is subject to penalties, up to and including closure.

Many of the compliance objectives are directly related to ethical issues. Keeping a customer's personal information private (Personally Identifiable Information or PII) is not only a regulation (Gramm-Leach-Bliley Act or GLBA, also known as the Financial Services Modernization Act of 1999) but is an ethically based decision to protect the bank's customers.

No regulations or compliance requirements apply to much of the day-to-day behavior of bankers. Bankers must keep customer information private, but there is nothing to prevent them from using a customer's perceptions that pay-to-play may influence their banker's loan decisions. Banks are required to be audited for their Information Security Program, a large part of which is concerned with protecting the privacy of the bank's customer's information, but banks are not audited for the ethical perceptions of the community.

Providing equal opportunity for loans to all people is an ethics-based law (Community Reinvestment Act, Pub.L. 95-128, Title VIII of the Housing and Community Development Act of 1977, 91 Stat. 1147, 12 U.S.C. $\$ 2901$ et seq.) that is audited for compliance. This law is designed to ensure that banks and savings associations meet the needs of all borrowers in their communities, including low- and moderate-income neighborhoods. Enforcement is based on audits of loans to low-income households and is not based on the community's perceptions of the bank's performance. This law is an example of how ethics and compliance often have the same goal of fairness to all. 
Most banks have an ethics policy for their employee that emphasizes protecting PII, treating people fairly, complying with all applicable laws and regulations, and being good citizens. As consumers, we want our bank to treat us fairly, honestly, and ethically in compliance with the law. Any perception that our bank is not treating us fairly may cause us to change banks or let others know our negative opinion of the bank. This perception of ethical fairness is not audited.

Bank customers should not perceive that they have to pay-to-play for banking services. Just as they would not expect to pay a bribe to get a loan, customers should not feel pressure to participate in community activities or organizations to qualify for a loan. If a loan officer belongs to a service club such as Rotary International, bank customers should not perceive that membership in the club influences the loan officer's banking decisions. The impression of favoritism to customers who "play" with bankers creates an ethical, but not a compliance, issue. Bankers are often active in community affairs and want to be known as supporters of the community in the hopes of being perceived as good for the community and the bank's customers.

This case is concerned with the behavior of bankers in their communities and their membership in local chambers of commerce and charitable organizations. The subject of our study is the regional president of a large national bank that operates in large areas of the United States. The regional president is responsible for more than 30 banks in the area that operate in different communities in a geographically wide area.

Our bank president is active in community organizations, charities, and the local chamber of commerce. His bank has a strong ethical code for its employees and expects all employees to behave in an ethical manner in their personal lives and as associates of the bank. The bank president has served as chair of the United Way and as president of the local Chamber of Commerce. He encourages his employees to participate and volunteer in community activities, charities, and organizations such as the chamber. His personal ethical standards and those of his employees go well beyond compliance with the law by focusing on high standards of fairness and honesty.

His community's chamber of commerce began a campaign to increase its membership and hired an Atlanta-based consulting firm to provide membership promotions. The promotions included prizes for members who recruited new individuals and businesses to join the chamber. Other banks in the community allowed their employees to participate in the membership drive and compete to earn cash prizes ( $\$ 50$ per new recruit) and awards for recruiting the most new members. Winners from other banks also had their photographs taken and were given publicity in local media and were recognized at chamber banquets. Personnel from our president's bank were noticeably absent from the dais during the award ceremony. Other bankers received publicity and cash for their efforts to increase the membership in a community organization considered an asset to the community.

\section{DISCUSSION}

- $\quad$ Why were employees of the president's bank not allowed to participate?

- What ethical issues arise in being rewarded financially for recruiting new members for a community organization?

- Is it fair to the employees to miss out on the cash rewards and recognition for helping a good cause?

Our banker has a strong sense of personal ethics that go beyond compliance and policy. He believes vigorously not only in banking and behaving ethically but in avoiding potential ethical conflicts of interest. In his personal ethical value system, the appearance of unethical behavior is just as bad as behaving unethically. Our banker does not want to ever participate in pay- to-play activities or have the possibility of customers thinking they have to pay-to-play. If a bank loan officer approaches a local business owner who is also a bank customer and asks the business owner to become a member of the chamber of commerce, the customer may feel that his chances for getting a loan are contingent on his joining the chamber. This perception may not reflect reality, but the perception may be that the customer must pay-to-play by joining the chamber. The bank does not base decisions on the customer becoming a chamber member, but our banker never wants a customer to believe that his joining the chamber has any influence on the loan decision process. 
The same holds true for charitable activities. If our banker is president of the United Way, he never wants the community to perceive that United Way donations influence banking decisions. Our banker wants to avoid the perception of pay-to-play and believes it is unethical even though it may not be covered by any compliance regulation.

Many banks support local high school and university athletic, artistic, and academic events. These same banks may also do business with the school or organization. Is it possible to donate to a good cause and still be seen as not trying to influence the banking choice of the school? If the bank does business with a university, donates athletic scholarships, and then accepts a seat on the team airplane for the basketball championships, what are the ethical implications? What are the public's perceptions of the bank's behavior? Should bankers accept free trips to the Super Bowl? To the Olympics?

\section{DISCUSSION}

- If the coach calls and says, "We have an empty seat on the team plane," what would you do as a bank president?

These decisions that have perceptual and ethical implications beyond compliance usually are not covered by formal policy. Donations of bank monies and volunteer activities are a traditional way for banks to contribute to their communities. Banks are expected to be good citizens, but what are the boundaries? Are they just buying good will or are they implying that the relationship is a pay-to-play reciprocity deal?

Other banks in our president's community have no problem with their employees participating in the chamber contest for new members. The other bank's employees earn cash prizes and are recognized at the banquet and in photographs in local publications. Will our president's employees feel they are somehow being denied an opportunity for monetary gain or recognition by the community? What can the bank do to overcome this perception by its employees? Are their internal programs at the bank to reward employees for community activities that do not give the impression of pay-to-play favoritism? What can our bank president do to prevent employees from feeling left out of rewards from the chamber or feeling resentful for not being allowed to take a courtesy flight to a basketball game?

Our bank president has formal procedures and policies in place to ensure that the bank complies with all applicable laws and regulations. He could follow a narrow compliance-based approach to his personal ethics as a banker. His employees would then be expected to comply only with legal requirements and not necessarily behave in an ethical manner that goes beyond compliance. The community's perceptions of the bank's and its employee's ethical standards of fairness and honesty are important to our banker. He wants to be perceived as being ethical 24 hours a day and asks that his employees also understand the importance of personal ethics in all of their behavior.

\section{DISCUSSION}

- $\quad$ Should these issues of ethical perceptions be regulated by federal or state agencies?

- $\quad$ Can we regulate perceptions?

- If a bank does not set its own ethical boundaries, should someone else step in? Can a bank use its ethical standards as a marketing tool?

- What would you do if you were a bank president?

\section{ACKNOWLEDGEMENT}

The author would like to thank the Daniels Fund Ethics Initiative at New Mexico State University for its support in creating teaching materials based on this case. 


\section{AUTHOR INFORMATION}

James A. Nelson, Ph.D. is Associate Professor of Information Systems in the College of Business at New Mexico State University. Jim is a Fellow of the Bill Daniels's Fund Ethics Initiative and does research and develops teaching materials on Ethics in Business and in Information Systems. He is a graduate of New Mexico State University, Drake University, and the University of Missouri-Columbia. E-mail: jnelson@ad.nmsu.edu

\section{NOTES}

